Bauxite Deposits of the Eufaula District, Alabama

GEOLOGICAL SURVEY BULLETIN 1199-E

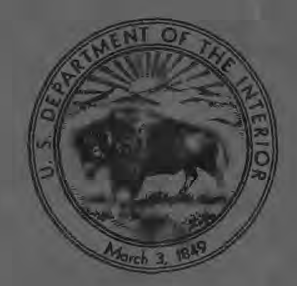




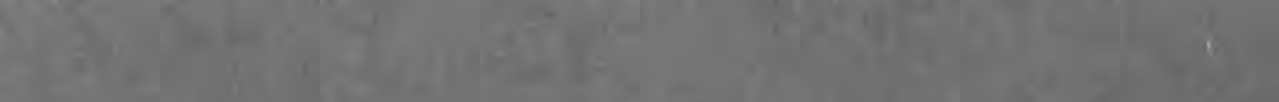

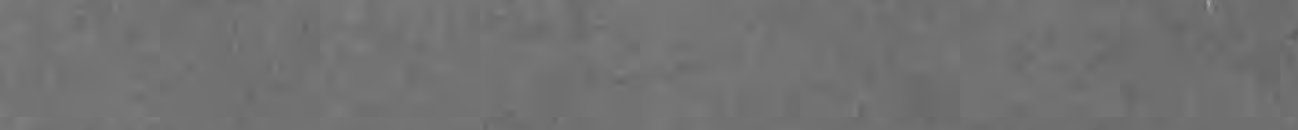

$18 x+x^{2}-x^{2}$

and

Wherp:

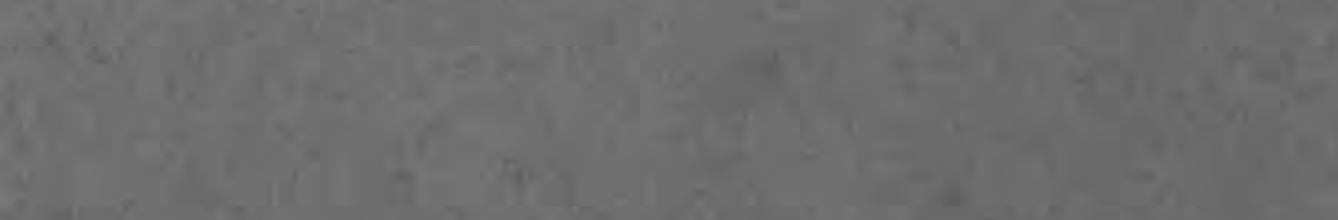

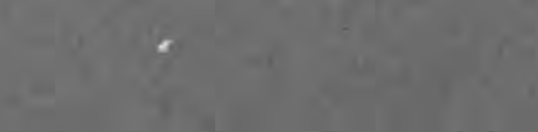

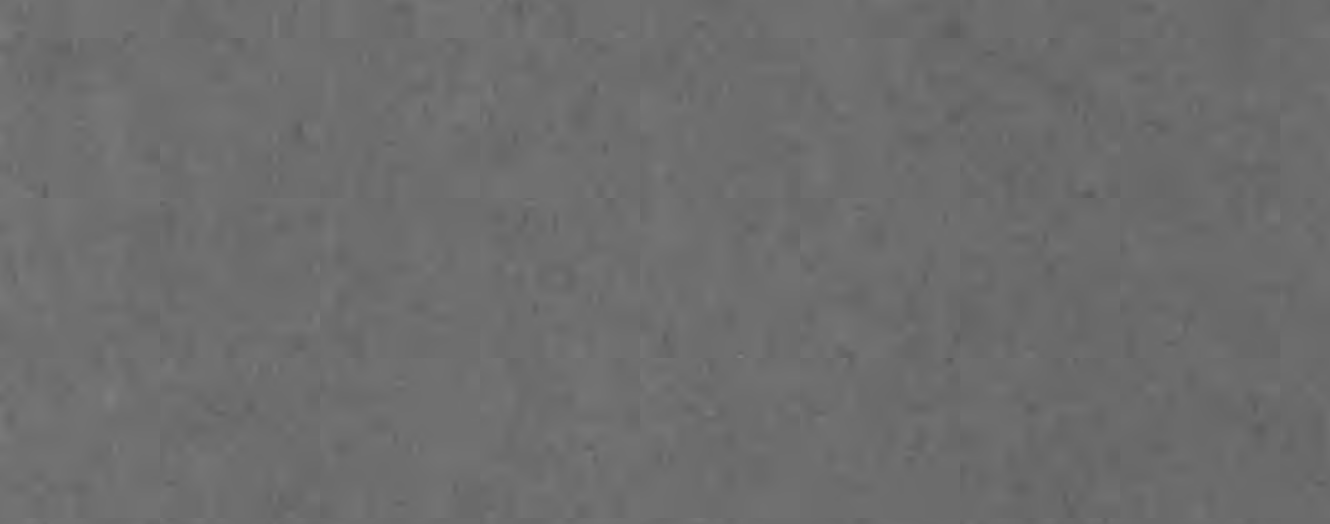

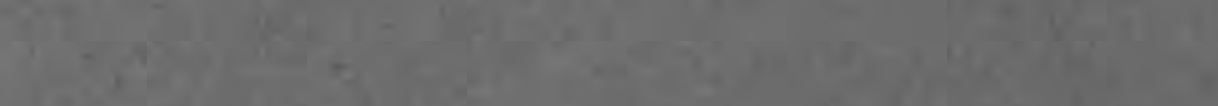

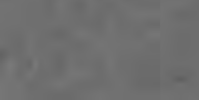

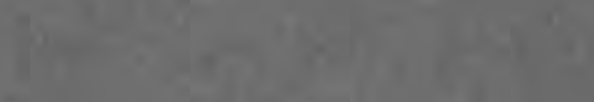
20
dise
cisition
$-40$
(N.
intisis g.

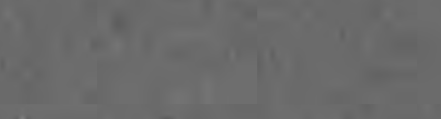

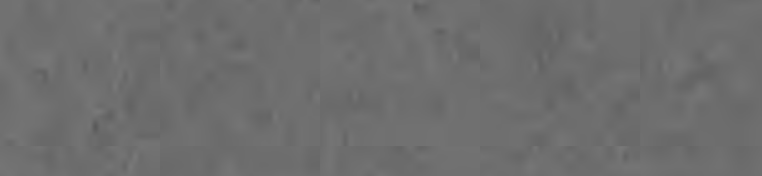
)

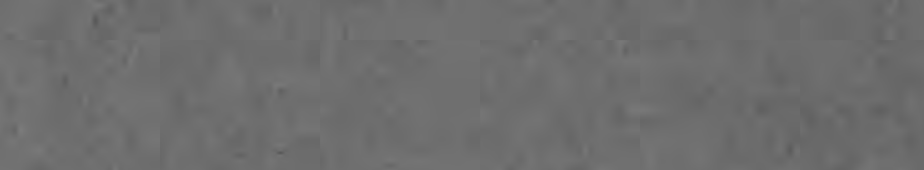

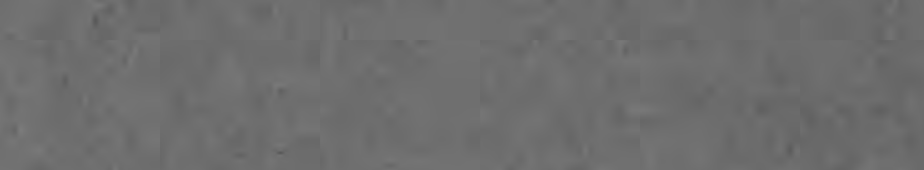
Q yux

kr. Pe $x^{2}$, in $^{2}$

xicsiluse

cind -3

Woper $x$ :

48

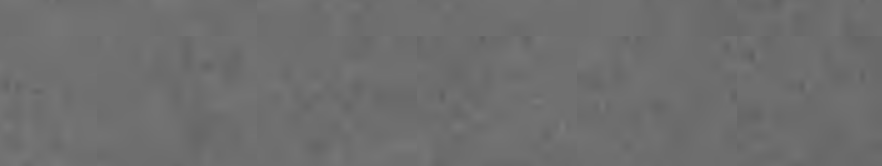

Grosinis:

s.magrian

.

$+4$

$-71$ 


\section{Bauxite Deposits of the}

\section{Eufaula District, Alabama}

By WALTER C. WARREN and LORIN D. CLARK

AUXITE DEPOSITS OF THE SOUTHEASTERN UNITED STATES

3 E O L O G I C A L S U R V E Y B ULLE TI N 1199-E

Distribution, occurrence, and resources of bauxite

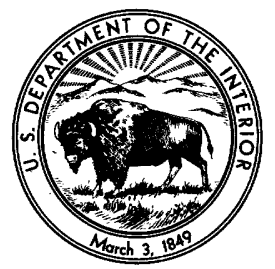




\section{UNITED STATES DEPARTMENT OF THE INTERIOR}

STEWART L. UDALL, Secretary

\section{GEOLOGICAL SURVEY}

Thomas B. Nolan, Director

The U.S. Geological Survey Library has cataloged this publication as follows:

\section{Warren, Walter Cyrus, 1907-}

Bauxite deposits of the Eufaula district, Alabama, by Walter C. Warren and Lorin D. Clark. Washington, U.S. Govt. Print. Off., 1964.

iii, 31 p. illus., fold. col. map (in pocket) diagrs. $24 \mathrm{~cm}$. (U.S. Geological Survey. Bulletin 1199-E)

Bauxite deposits of the sontheastern United States.

Bibliography: p. 31 .

1. Bauxite-Alabama. 2. Geology-Alabama-Eufaula region. I. Clark, Lorin Delbert, 1918- joint author. II. Title. (Series) 


\section{CONTENTS}

Page

Abstract

Introduction

Acknowledgments .

History

Drainage and relief

Physiography

Stratigraphy

Upper Cretaceous.

Tertiary

Midway Group (Paleocene)

Wilcox Group (Eocene)

Nanafalia Formation

Tuscahoma Formation

Bashi(?) Marl Member of the Hatchetigbee Formation.... 16

Structure.......

Bauxite. .

Physical characteristics._-_._. 18

Occurrence . . . .

Mineralogy

Chemistry

Summary of drilling program

Utilization and grade of ore

Production and reserves...

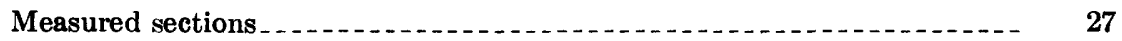

Primarily of the Nanafalia Formation.

Primarily of the Tuscahoma Formation

References cited. 31

\section{ILLUSTRATIONS}

Page

Plate 1. Geologic map of the Eufaula district........ In pocket

Figure 1. Correlation chart showing units of the Nanafalia Formation - E10

2. Sketch of east end of the Griffin mine (Alcoa Mining Co.), NE1/4 sec. 4, T. 8 N., R. 27 E. .

3. Correlation chart showing units of the Nanafalia and Tuscahoma Formations and the Bashi(?) Marl Member of the Hatchetigbee Formation . . . . . . . . . . . . . . . .

4-9. Photographs showing:

4. Sinkhole structure exposed in roadcut, $N E 1 / 4$ sec. $17, T$. 8 N., R. 27 E.

5. High-grade, low-iron bauxite containing large compound pisolites.

6. Red high-iron bauxite

7. Part of the Roan Baker No. 3 mine (Alcoa Mining Co.), SE1/4 sec. 27, T. 9 N., R. $27 \mathrm{E}$

8. Part of the Sam Smith No. 5 mine (Alcoa Mining Co.), NE14 sec. 18, T. 9 N., R. 28 E

9. Part of the Crawford Scott mine (Bauxite Co. of Alabama), NE 144 sec. 35, T. 9 N., R. 27 E........... 



\title{
BAUXITE DEPOSITS OF THE SOUTHEASTERN UNITED STATES
}

\section{BAUXITE DEPOSITS OF THE EUFAULA DISTRICT, ALABAMA}

\author{
By Walter C. Warren and Lorin D. Clark
}

\begin{abstract}
The Eufaula bauxite district is on the Coastal Plain of Alabama, in Barbour and Henry Counties, near the southeast corner of the State. The formations exposed .in this district are: the Ripley Formation and the Providence Sand of Late Cretaceous age; the Midway Group of Paleocene age; the Wilcox Group which consists of the Nanafalia and Tuscahoma Formations and probably the Bashi Marl Member. of the Hatchetigbee Formation, all of Eocene age ; and undifferentiated younger beds.

The bauxite forms central cores within kaolin lenses in terrestrial beds that are considered to be a continental facies of the Nanafalia Formation. Extensive subsurface solution of limestone of the Midway Group has caused much irregular slumping of overlying formations and is aceompanied by distortion and faulting of bauxite and clay bodies.

Total production of bauxite from the district, through 1943, was estimated to be 400,000 long tons, and reserves of commercial grades of bauxite under overburden not too great to permit profitable mining are estimated to be 350,000 to 600,000 long tons. The U.S. Geological Survey and the U.S. Bureau of Mines cooperated in a joint program of prospecting and drilling which resulted in the discovery of 45 bauxite deposits, totaling 300,000 long tons of commercial grades of ore, by the end of 1943.
\end{abstract}

\section{INTRODUCTION}

Study of the Eufaula bauxite district, Alabama, by the U.S. Geological Survey began in November 1941 and continued until February 1944, as part of the search for strategic and critical minerals by the U.S. Department of the Interior. The Eufaula bauxite district (pl. 1) covers an area of about 200 square miles in Barbour and Henry Counties near the southeast corner of Alabama. Baker Hill is the only settlement within the district. Clayton, the county seat of Barbour County, is several miles northwest of the district; Abbeville, the county seat of Henry County, is 8 miles south of it; and Eufaula, the largest town nearby, is 6 miles to the north.

Geology and topography were mapped on aerial photographs with the aid of a stereoscope and a surveying aneroid barometer. In the 
final compliation, a base map was constructed from close plane-table traverses, carrying altitudes over a network of roads. The photographs were adjusted to the traverses, and the data were transferred to the final map. Section lines were used to adjust pictures not crossed by these traverses.

\section{ACKNOWLEDGMENTS}

The mapping was done by W. C. Warren, assisted at various times by A. D. Zapp, D. D. Arsen, L. D. Clark, J. I. Tracey, Jr., M. L. Lucas, and E. E. Pugh, Jr., and was under the supervision of W. H. Monroe. The U.S. Bureau of Mines and the U.S. Geological Survey cooperated in a joint drilling program, which continued intermittently during and after the mapping. Regional stratigraphic studies by F. S. MacNeil contributed to an understanding of the local geology.

We wish to express appreciation to our field assistants who contributed so fully to the data in this report and to geologists working on bauxite in other areas for their many helpful suggestions. Especially are we indebted to Lyman D. Toulmin, Jr., who generously contributed pertinent notes from his work in Alabama, and to the mine operators in the district, without whose cooperation the work would have been greatly handicapped.

\section{HISTORY}

In 1923, a year after bauxite was discovered in the vicinity of Baker Hill by Pete Floyd, a local farmer, the Republic Mining and Manufacturing Co. (now Alcoa Mining Co.) became interested in the field. R. E. Rettger (1925, p. 671-672) prospected the area for the company during parts of 1923 and 1924, and Walter B. Jones (1929 and 1940) studied the deposits in 1925 and later.

Mining was begun by the Republic Mining and Manufacturing Co. in 1927, but not until 10 years later did a second company, the Floridin Co., enter the district to mine red ore. Other companies were organized during 1940 and 1941, and in 1943 five producing companies were active in the field: Alcoa Mining Co. (Republic Mining and Manufacturing Co.) ; Bauxite Co. of Alabama; Barbour Bauxite Co.; D. M. Wilson Bauxite Co.; and the General Ore Co. By 1952, only the Alcoa Mining Co. and the D. M. Wilson Bauxite Co. were still mining.

\section{DRAINAGE AND RELIEF}

The streams draining the Eufaula district are separated into two groups by a divide which extends from near the northwest corner through Baker Hill to the southeast comer of the district. This divide has the form of a cuesta and will be referred to as a geologic feature, the Baker Hill cuesta (pl. 1). The streams flowing down the steep 
northeast slope of the cuesta turn east and drain into the Chattahoochee River, by far the largest river in the region. Tributaries of the Chattahoochee have relatively short course and high gradients.

The gentle southwest slope of the cuesta is drained by the East Fork of the Choctawhatchee River and by Abbie Creek, a tributary of the Chattahoochee. The streams of this part of the district are generally sluggish and bordered by swamps. However, most of the streams on. both. sides of the cuesta are spring fed and flow the year around.

Except for a few notches, the crest of the Baker Hill cuesta throughout its length varies less than 50 feet from an altitude of 500 feet. The west edge of the bauxite district lies on the divide between the West Fork and the East Fork of the Choctawhatchee River, and the highest point on this divide, in the area mapped, is about 630 feet above sea level. The lowest point in the district, on the Chattahoochee River, is at an altitude of about 110 feet. Therefore, total relief in the area is about 500 feet. The steep northeast slope of the Baker Hill cuesta has a local relief of more than 200 feet in half a mile. Gullies along the cuesta are in some places more than 150 feet deep.

\section{PHYSIOGRAPHY}

The Eufaula bauxite district is on the East Gulf Coastal Plain section of the Coastal Plain province, 40 miles south of the edge of the Piedmont province. The higher parts of the district approximate a common level and are fairly flat topped; they seem to be parts of a high plain that ranged from about 550 feet to 650 feet above sea level. The age of the high plain is uncertain but is probably post-Miocene. The southward-flowing streams of the southwestern part of the area were consequent on the gently seaward dipping slope of this high plain and once drained more of the area than they do now. After or during uplift of the region, the Chattahoochee River cut down faster than the other. streams, and the tributaries flowing eastward into the Chattahoochee cut into the high plain to form the Baker Hill cuesta. These tributaries are still shifting the crest of the cuesta southwestward, and results of stream piracy are evident in sec. $2, \mathrm{~T}$. 9 N., R. 28 E. Northwestward along the scarp in several places, the stream pattern also suggests reversals of drainage.

In the northeastern part of the district a well-defined terrace, probably not older than the Pleistocene, stands about 150 feet above the Chattahoochee River. Downstream, where the river cuts through the Baker Hill cuesta, the terrace is extensively dissected, and its presence is attested only by scattered patches of gravel at about the same altitude as the clearly defined part of the terrace. Southwestward from the edge of the terrace, nearly to the foot of the scarp of the Baker 
Hill cuesta, the topography is gently rolling, and the hilltops rise about 70 feet above the terrace level at the river. Except that the valleys crossing this rolling terrain have been subsequently incised, the surface seems to be nearly that of the original gently sloping terrace. Bauxite deposits exposed in this early cycle of erosion commonly form a feature known locally as "bust-ups". The "bust-ups" consist of small knolls held up by a core or capping of bauxite that is resistant to erosion because of impregnation with iron oxide.

Steep-walled erosion gullies are common un slopes of even moderate gradient throughout the region and are a.result of torrential rainfall working on slightly consolidated sediments. Only a few years is required for the formation of gullies, and all cultivated fields, except those that are nearly level, must be terraced. Although these gullies are the despair of farmers and conservation officials, they afford exposures which greatly aid in studying the geology of the district.

\section{STRATIGRAPHY}

The rocks exposed in the Eufaula bauxite district include limestone, chert, shale, and unconsolidated clays and sands, ranging in age from Late Cretaceous through Oligocene. They consist of the upper part of the Ripley Formation and the overlying Providence Sand of Late Cretaceous age; the Midway group of Paleocene age; the Wilcox Group of Eocene age, which niviudes the Nanafalia and Tuscahoma Formations and the Bashi (?) Marl Member of the Hatchetigbee Formation; and the post-Wilcox beds, which are undifferentiated on plate 1. The post-Wilcox beds include sand of the Claiborne Group of middle Eocene age, exposed near Texasville and near the south edge of the district on the divide followar by U.S. Highway 241, and, immediately southwest of Baker Hill, extensive patches of weathered chert and clay residuum derived from the Jackson Group of Late Eocene age and from Oligocene limestone. Probably none of the residuum is in place.

\section{UPPER CRETACEOUS}

The oldest rocks exposed in the bauxite region are of Late Cretaceous age. They include the upper part of the Ripley Formation and the overlying Providence Sand. The two formations were not differentiated in mapping, nor were detailed studies made, inasmuch as they are below the horizon at which the bauxite occurs. However, the top of the Cretaceous is important because the Providence-Midway contact provides the only reliable structural datum plane in the district.

The uppermost beds of the Providence Sand along the Chattahoochee River are very dark carbonaceous micaceous sandy sha]es which feel greasy when wet. Westward from the river the uppermost beds 
are nonmarine sands and white to gray clays that look very much like beds in the Nanafalia Formation. A stratigraphic section, including the top of the Providence Sand and the lower part of the Midway Group, is exposed along the west bank of the Chattahoochee River in sec. 3, T. 8 N., R. 29 E.

Midway Group :

Thickness

7. Limestone, hackly, fossiliferous (feet)

6. Sandstone, calcareous, coarse-grained; contains , scattered pebbles as much as one-quarter inch in diameter

5. Limestone, yellow, fossiliferous; contains variable amounts of coarse sand; some iron-stained nodules at base-..........-.

4. Sand, blue, calcareous at base and grading upward into blue sandy shale at top.

3. Limestone, yellow, sandy, fossiliferous; includes 4 to $\mathbf{1 0}$ feet of loose yellow sand at base.

Providence Sand:

2. Shale, black, carbonaceous, micaceous, sandy; contains scattered stunted ammonites and other marine fossils

1. Sandstone, bluish-gray, calcareous, fossiliferous

Where U.S. Highway 241 crosses White Oak Creek, marine beds of the Providence are exposed on the north side of the creek at the foot of the hill. A thick sand bed that is probably a nonmarine sand of the Providence is exposed on the south side of the creek, at a slightly higher altitude.

\section{TERTIARY}

\section{MIDWAY GROUP (PALEOCENE)}

The Midway Group in this district consists mainly of limestone containing minor amounts of sand and clay. It is represented here only by the Clayton Formation, which appears to be divisible into two unnamed units not differentiated in this report.

Chalky limestone composed largely of algal remains crops out along the Chattahoochee River, downstream from where the preceding section was measured. Although exposures are fairly continuous along the river, stratification in this limestone unit is too poor for accurate measurements of its thickness. Enough bedding is evident, however, to give some idea of the structure and to permit a rough estimate of the thickness. Three geologists, traversing the river by boat, independently estimated the thickness of the limestone above the measured section as ranging from 75 to 100 feet. The total thickness of the Midway Group on the Chattahoochee River appears to be $135 \pm 20$ feet. This is considerably less than earlier estimates of 218 feet and 298 feet made by Langdon (1894, p. 369, 418, and 743), particularly as his beds 37 and 38 (Langdon, 1894, p. 743), included in the Creta- 
ceous, appear to correspond to beds 3 and 4 of the Midway Group discussed in the preceding section.

Rotten algal limestone, resembling that at the top of the Midway Group on the Chattahoochee River at Fort Gaines, Ga., is exposed in the ditch and adjacent county roadcut in the $\mathrm{SW} 1 / 4$ sec. $36, \mathrm{~T} .9 \mathrm{~N}$., R. 28 E., between the big bend in the road and the first creek crossing north of the bend. A large variety of small fossil forms yielded by this limestone were submitted to Miss Julia Gardner, who reported (written commun. to F. S. MacNeil, 1942) that she and her colleagues had found in the collection 17 species of Bryozoa, brachiopods considered to be new species of Argyrotheca, and small oysters that are almost certainly Ostrea pulaskensis, one of the guide fossils of the lower part of the Clayton Formation. This exposure is apparently at least 100 feet above the base of the Midway Group, and the lithology resembles the upper part of the group.

The base of the Midway Group is exposed in several places between the Chattahoochee River and the west side of the district. In each exposure the limestone of the Midway Group is underlain by white to yellow basal sand resting on clay or micaceous sand of the Providence Sand. The basal sand of the Midway Group is rarely micaceous. Although fossils indicate a long lapse of time between the Cretaceous and the Paleocene, there is no observable erosional or structural unconformity.

In most exposures of the Midway Group the limestone has been thoroughly leached, and only crumpled decalcified clays and sands, with or without chert fragments, remain. Extensive subterranean solution of the limestone is attested not only by outcrops of the crumpled residual clays and sands, but also by sinks and random dislocations in the overlying beds. Where the limestone has been completely dissolved away, the thickness of the Midway Group may be less than 25 feet, as shown in a roadcut about 200 yards south of the bridge across Thomas Mill Creek in sec. 5, T. 8 N., R. 29 E., where the Midway consists of basal sand overlain by brown crumpled clay. Here less than 25 feet of the Midway Group separate the Providence Sand from the Nanafalia. Another locality where the residuum of the leached limestone may be observed is on the west side of the East Fork of the Choctawhatchee River in sec. 28, T. 10 N., R. 27 E., in a roadcut where a country road ascends from the valley. The section is as follows: At the bottom of the hill, medium micaceous sand of the Providence Sand of Late Cretaceous age crops out. About 20 feet above stream level the Providence Sand (a) is overlain by 2 feet of coarse' sand containing some mica and glauconite (b), representing a basal sand unit of the Clayton Formation. This unit is overlain by 
coarse glauconitic, nonmicaceous sand which grades up through fine sand into the next unit, a decalcified brown clay (c) containing lumps of chert. The brown clay grades upward through greenish-gray bentonitic clay (d) into another layer of decalcified brown clay (e) and then into brown, fine, micaceous sand (f) that is peculiarly laminated and was probably also originally calcareous. This brown sand is overlain unconformably by fine gravel $(\mathrm{g})$ of the Nanafalia Formation, in which the pebbles are as much as half an inch in diameter. The maximum thickness of the Midway Group here is about 40 feet, but this thickness includes.unleached limestone, and the limestone has probably not been dissolved for a very great distance back from the hillslopes. Probably some of the thinning of the Midway Group ascribed to solution of the limestone is actually due to erosion prior to deposition of the overlying beds of the Nanafalia, but thinning due to erosion is considered to be minor.

The limestone has been locally replaced by chert, and in such places the top of the Midway Group may extend 50 feet higher than the top of the decalcified residuum of surrounding areas.

\section{WILCOX GROUP (EOCENE)}

The Wilcox Group in the district consists of a terrestrial phase represented by the Nanafalia Formation and a later marine phase represented by the Tuscahoma Formation and the Bashi(?) Marl Member of the Hatchetigbee Formation. The Wilcox Group is equivalent to the entire lower Eocene.

\section{NANAFALIA FORMATION}

The sands and clays here described as the Nanafalia Formation were tentatively considered by Cooke (in Adams and others, 1926, p. 257) to be part of the Midway group, and Jones (1940, p. 67-68) and Rettger (1925, p. 672-673) accepted Cooke's assignment. However, these beds occupy the same stratigraphic interval as the marine Nanafalia beds at Fort Gaines, Ga., only 3 miles southeast of the area mapped. At Fort Gaines, the bluffs on the east side of the Chattahoochee River afford excellent exposures of the Nanafalia Formation. Upstream and downstream from the highway bridge over the river, the lower and upper parts of the Nanafalia are well exposed.

The beds in the bauxite district that are referred to the Nanafalia Formation are unconsolidated sands, kaolinitic sands, bauxite, and kaolins that are in part carbonaceous and in part bauxitic. The contact between the continental beds of the Nanafalia Formation and the limestone of the Clayton Formation is rarely exposed, but in the scarce outcrops and in drill cores, medium sand or coarse sand and 
gravel of the Nanafalia rest on weathered limestone. The contact is everywhere sharp and is undoubtedly unconformable. Because the Nanafalia in the bauxite district has been disturbed by collapse into sinkholes formed as a result of leaching of the underlying limestones of the Clayton Formation, determination of the depositional form of the Nanafalia or finding complete sections of the formation is very difficult.

The Nanafalia Formation south of the bauxite district is represented by a marine facies. The marine beds were studied in less detail than the nonmarine beds, and most of the following discussion concerns the nonmarine beds with which the bauxite is associated. The strandline may have been near the south edge of the district, for there the bedding suggests marine or brackish-water deposition. Formation of sinkhole structures in the limestone after deposition of the Nanafalia, but before deposition of the Tuscahoma, is indicated by relations at the Crawford Scott mine, NE $1 / 4$ sec. 35, T. 9 N., R. 27 E. Here, cuttings from an auger hole indicate that the top of the Clayton Formation is more than 40 feet lower than an outcrop of Clayton a quarter of a mile to the north; in addition, the bauxite beds in the mine dip west rather steeply as a result of slumping, whereas the overlying Tuscahoma is horizontal.

The measured sections shown in figure 1 represent rocks exposed in gullies and bauxite pits on the northeast slope of the Baker Hill cuesta, with the exception of section $F$, which is exposed in the river bluff at Fort Gaines, Ga. Sections $A$ through $E$ are described in detail beginning on page E27; section $F$ is described on pages E11 and E12.

In many places the nonmarine facies of the Nanafalia Formation seems to be divisible into two parts: an upper part consisting of sand and clay, and a lower part in which the bauxite and kaolin lenses occur. Both units are shown in the cut in the overburden in the east side of the Griffin mine (fig. 2). This division into two units is more evident in the marine facies that is well exposed at Fort Gaines.

As shown in the measured sections, the sand of the Nanafalia Formation is micaceous, is commonly crossbedded, and commonly carries clay balls, most of which are less than an inch in diameter. Bromoform separations were made on two samples from the Nanafaliaone, a rather coarse sand from near the base of the formation (Bur. Mines drill hole in sec. 13, T. 9 N., R. 27 E.), and the other, a kaolinitic fine sand from an outcrop near the top of the formation (sec. 28, T. 9 N., R. 28 E.). The minerals found in the two samples were the same. The light fraction consisted of sharp, angular grains of quartz. The minerals in the heavy fractions were: 


\begin{tabular}{|c|c|}
\hline Magnetite & $\begin{array}{l}\text { Relative abundance } \\
\text { Very abundant }\end{array}$ \\
\hline Ilmenite-_-_- & Do. \\
\hline Muscovite_-_- & Common to very abundant \\
\hline Tourmaline & Abundant \\
\hline Rutile_-..-- & Common to very common \\
\hline Kyanite & Common \\
\hline Hypersthene-1 & Scarce to common \\
\hline Zircon & Do. \\
\hline Glaucophane(?) & Very rare \\
\hline Ceylonite(?) & Do. \\
\hline
\end{tabular}

In one sample the zircon was slightly altered; otherwise the minerals appeared very fresh.

In some places the entire section of the Nanafalia Formation is sand, but in others relatively pure quartz sand in the lower part of the section grades up through fine micaceous sand and micaceous kaolin into kaolin. In some places carbonaceous material occurs above or below the kaolin. The kaolin seems to be in the form of lenses, some of which have cores of bauxite or bauxitic clay. The kaolin grades upward rather sharply into fine micaceous sand which, in some places, alternates with thin beds of sandy kaolin. Locally, the kaolin lenses or the beds above them have been channeled and are unconformably overlain by sands which grade upward into thin kaolin beds. These channel sands cannot be distinguished from sands lower in the section. The kaolin beds in these channels, however, are thin as contrasted with the fairly thick lenses that occur in the main part of the formation, and no bauxite is known to occur in them.

The nonmarine facies of the Nanafalia is characterized by abrupt lateral changes in lithology and discontinuous lithologic units, as suggested by the variety of units in the formation shown in figure 1 . Changes within very short distances are common. Sandy clay can be seen to pass abruptly into crossbedded sand in an exposure in a gully in the eastern suburbs of Baker Hill (bed 2, section $A$, fig. 1). Little correlation can be found between units exposed in the upper part of the Nanafalia in the Crawford Scott mine (section $D$, fig. 1) and a section a quarter of a mile to the west, which is as follows: In descending order the units are Tuscahoma Formation; white micaceous, kaolinitic sand; carbonaceous shale; gray shale showing a very irregular contact with the underlying kaolin; a poorly exposed interval, below which 5 feet of bauxite or bauxitic clay crops out; and, finally, kaolin containing tiny pellets of siderite and grading downward into micaceous clay. The carbonaceous and gray shales in this section apparently correspond to part of the kaolinitic sand in the section exposed in the mine. The siderite here is below the bauxite, whereas in the mine it is above. 


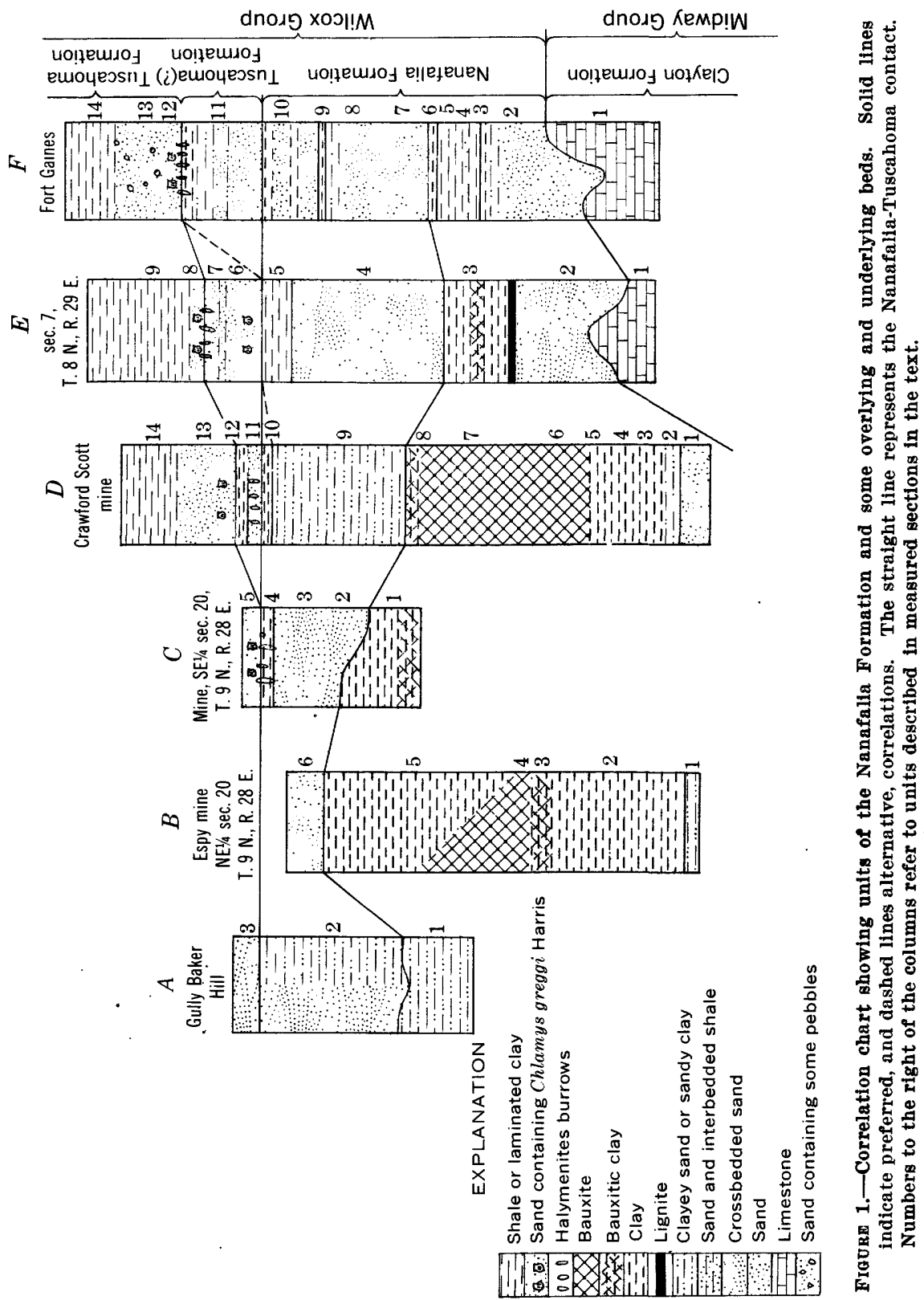




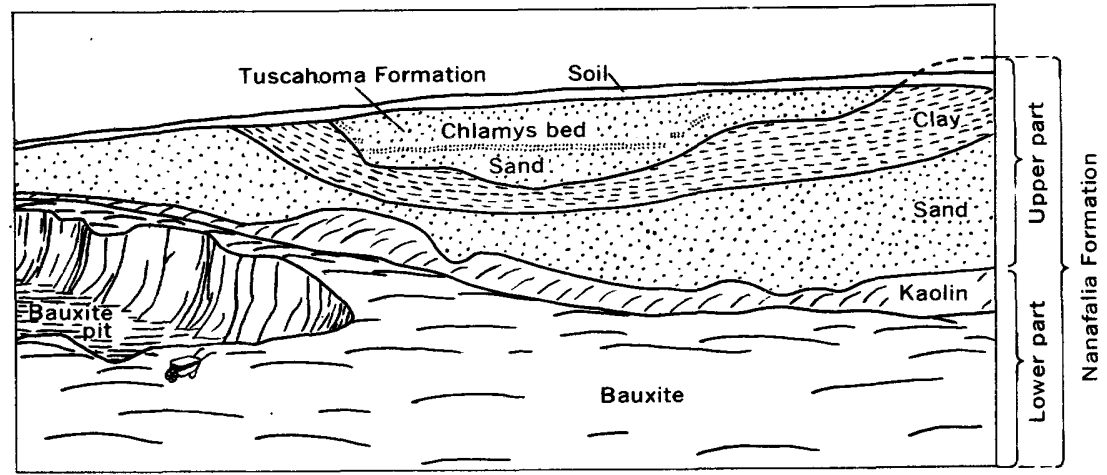

Figure 2.- Sketch of east end of the Griffin mine (Alcoa Mining Co.), NE $1 / 4$ sec. 4, T. 8 N., R. 27 E., looking eastward. The cut in overburden in the east wall shows slumping of the Nanafalia and Tuscahoma Formations into a shallow sinkhole structure. The division of continental sediments of the Nanafalia into the bauxite- and kaolin-bearing lower part and the sand and clay of the barren upper part can also be seen. Scale indicated by wheelbarrow.

The Nanafalia Formation appears to range in thickness from 60 to 100 feet, and the average thickness is probably about 80 feet. Because of gradual slumping of the residuum downhill as the limestone of the Midway was leached, the apparent thickness of the Nanafalia at many localities may be appreciably greater than the true thickness. Along a roadcut in sec. 36, T. 9 N., R. 28 E., the top of the Midway is 80 feet vertically below the base of the Tuscahoma; drill holes at scattered localities also indicate a thickness of at least 80 feet for the Nanafalia Formation.

The marine facies of the Nanafalia is very well exposed near Fort Gaines. In section $F$ (fig. 1), beds 1 to 10 inclusive were measured about 100 yards downstream from the highway bridge, where a sewer empties into the Chattahoochee River; and beds 1, 2, and 7 to 14, inclusive, were measured abcut 100 yards upstream from the bridge. The claystone, bed 9, was used as a guide horizon in correlating the sections above and below the bridge.

Bed 1 (section $F$, fig. 1 ) is the top of the Clayton Formation of the Midway Group. Potholes or small sinkholes are numerous in the top of the limestone in this vicinity, and some of these depressions contain white micaceous sands and kaolinitic sands similar to those surrounding the bauxite bodies.

Beds 2 to 10, as indicated by their fossils, represent the Nanafalia Formation. The fossils in bed 11 are poorly preserved and could be either Tuscahoma or Nanafalia forms. On the basis of his regional studies in comnection with the bauxite program, F. S. MacNeil considers bed 11 to be basal Tuscahoma. The same bed probably occurs locally in the eastern part of the bauxite district and extensively in the western part. 


\section{Section about 100 yards dounstream from bridge}

Nanafalia Formation:

Thickness

(feet)

10. Clay, sandy, soft, fossiliferous, grading up into fine yellowish sand-

9. Claystone, hard, ledge-forming, very fossiliferous

8. Sand, coarse, iron-stained; contains large mica plates. Grades upward into gray clayey sand with cherty clay balls. Large ostreas 3 feet above base.

7. Clay, gray, and yellow sand, irregulariy interbedded. Lamination irregular to obscure

6. Claystone, light-gray, silty. Fractures conchoidally, contains Foraminifera (?)

5. Shale, dark-gray, carbonaceous, interbedded irregularly with fine sand. Fragmentary fossils

.4. Sand, white, coarse, micaceous, irregularly stained with iron. Scarce pebbles as much as $7 \mathrm{~mm}$ in diameter

3. Sand and shale, carbonaceous

2. Sand, coarse, clayey, grading upward into gray sandy clay, which grades into the overlying bed. Contains several lentils of limestone having a maximum thickness of $1 \mathrm{ft}$. Fossiliferous throughout (corals, Turritella mortoni Conrad, pelecypods, and a prominent zone of Ostrea thirsae Gabb)

Clayton Formation :

1. Limestone, yellow, chalky, friable. Top is highly irregular, having a relief of $11 \mathrm{ft}$ in horizontal distance of $30 \mathrm{ft}$

On the basis of fossils, Miss Julia Gardner considered bed 12 to be of Tuscahoma age. Beds 12 and 13 form a characteristic unit which has been traced along the northeast side of the Baker Hill cuesta almost without break from Fort Gaines nearly to Baker Hill. The unit also appears on the southwest slope of the cuesta where streams have cut through the overlying beds. The little pecten Chlamys greggi Harris is the most common form in this unit and is an excellent guide fossil, as it is not known to occur in the Nanafalia nor in beds higher than bed 13 (fig. 1) of the Fort Gaines section. In the eastern part of the area mapped, the ('hlamys bed in most places lies directly on the white sands and kaolins referred to herein as the continental facies of the Nanafalia Formation. Thus, these white sands and kaolins are overlain and underlain by the same beds that overlie and underlie the marine Nanafalia Formation at Fort Gaines. Some of the beds of the Nanafalia at Fort Gaines are probably brackish-water deposits, as they are carbonaceous and are not fossiliferous. The strandline probably fluctuated between the site of Fort Gaines and a point several miles up the river. Three miles north of Fort Gaines in the southeast corner of the mapped area, some well-bedded clay is exposed in a small gully immediately west of the road and 200 yards south of Hardridge Creek (sec. 26, T. 8 N., R. 29 E.). Although this clay is unfossiliferous, it may represent the marine Nanafalia Formation. 


\section{Section about 100 yards upstream from bridge}

Tuscahoma Formation :

14. Shale, sandy at base

13. Sand, containing scattered pebbles, glauconitic, nunlerous limonitic partings

12. Sandstone, calcareous cement. Very glanconitic, full of large ostreas, venericardias, Chlamys greggi Harris, and other forms. Halymenites burrows extend about 6 in. into underlying bed and are flled with loose glauconitic sand containing many shells of Chlamys greggi Harris. Bed dies out laterally within 100 yds.-

Tuscahoma (?) Formation :

11. Sand, yellow, soft, containing irregular calcareous concretions in lower part. Coarse in lower part, grades upward through fine sand to calcareous, silty, fossiliferous clay at top-..--.---

Nanafalia Formation :

10. Clay and sand, irregularly interbedded; fossiliferous at base;

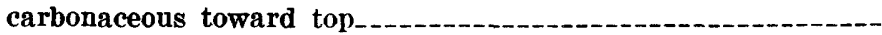

9. Claystone, hard, ledge-forming, very fossiliferous; varies somewhat in thickness

8. Sand, yellow, coarse, micaceous; grades up into clayey sand with gray cherty (?) patches. Scattered fossils

7. Clay, dark-gray, sandy; hard, very micaceous, lower part concealed_

6-3. Concealed

2. Sand, yellow, clayey, friable; poorly preserved fossils. Contains mica and coarse angular glassy quartz. Grades up into gray sandy clay containing calcareous concretions as much as $1 \mathrm{ft}$ in diameter. Top concealed.......

Clayton Formation:

1. Limestone, very fossiliferous, having some parts composed largely of shell fragments and algal remains. Limestone is white and soft on fresh exposures but weathers hard and light gray......

In the southwestern part of the mapped area, exposures of the Nanafalia apparently represent a transitional facies between the marine and nonmarine parts of the formation. Here, the Nanafalia is composed largely of sand, containing much clayey sand and thin lenses of waxy, sandy, micaceous, gray clays, and is unlike either the marine or nonmarine facies of the formation. The poor sorting of some of these deposits suggests that the clay fraction was flocculated by saline water and settled with the sand. Rare lenses of kaolin in this area contain only low-grade bauxite. In the southwestem part of the mapped area, marine beds southwest of Ham Creek probably correspond to the upper barren part of the continental Nanafalia in the rest of the bauxite district. This barren marine part of the Nana- falia is mapped with the Tuscalioma Formation sonthwest of Ham Creek.

Many bauxite pits and roadcuts throughout the bauxite district expose deposits of crossbedded coarse sand-commonly containing 
clay balls-that fill irregularities in the top of the Nanafalia Formation. The irregularities are both erosion channels and sinks formed by collapse of Nanafalia deposits into caverns in the underlying limestone of the Midway. The lithology of these sand deposits closely resembles that of the Nanafalia, but because of their stratigraphic position, their age is uncertain, and they could be either Nanafalia or an early, continental phase of the Tuscahoma Formation.

\section{TUSCAHOMA FORMATION}

The Tuscahoma Formation is a marine deposit in the district and is represented by four members: (1) A basal member of white sandy clay or coarse red sand, present as discontinuous patches in parts of the bauxite field and possibly the equivalent of bed 11 (fig. 1) in the Fort Gaines section; (2) a coarse glauconitic sand member that contains Chlamys greggi Harris and is represented by beds 12 and 13 of the Fort Gaines section; (3) a light-gray or green shale member; and (4) at the top, a fine red sand member which appears to be a weathered arkose. Measured sections of the Tuscalioma are shown in figure 3 and described on pages E30 and E31.

In the northern part of the area mapped, where the basal bed of the Tuscahoma is locally present, it is typically composed of bedded white sands and sandy clays, and its contact with the underlying Nanafalia is unconformable. In the southwestern part of the area, where the bed is more extensive, it consists of coarse, poorly sorted red sand and contains quartz pebbles as much as an inch in diameter and large chunks and logs of silicified wood. Glauconite and Halymenites burrows are common in this part of the bed. The contact with the overlying Chlamys bed is in most places indistinct, but the contact with the underlying Nanafalia formation is unconformable. This basal member is 3 to 15 feet thick.

In the next higher member, within the interval represented by beds 12 and 13 (fig. 1) of the Fort Gaines section, the pecten Chlamys greggi Harris is nearly everywhere present. Large ostreas, venericardias, turritellas, corals, and other fossils are abundant locally. The Chlamys bed is composed of coarse, poorly sorted sands with varying amounts of clay. It commonly contains clay balls and in places large flakes of mica. The bed is 1 to 15 feet thick but is about 12 feet thick throughout most of the area.

Secondary induration is a common feature of the Chlamys bed, a hard hackly ferruginous sandstone probably being produced by weathering of the abundant glauconite and redeposition of the iron as an oxide. This bed is the most resistant unit anywhere near that horizon in the section, and commonly forms low topographic benches. 


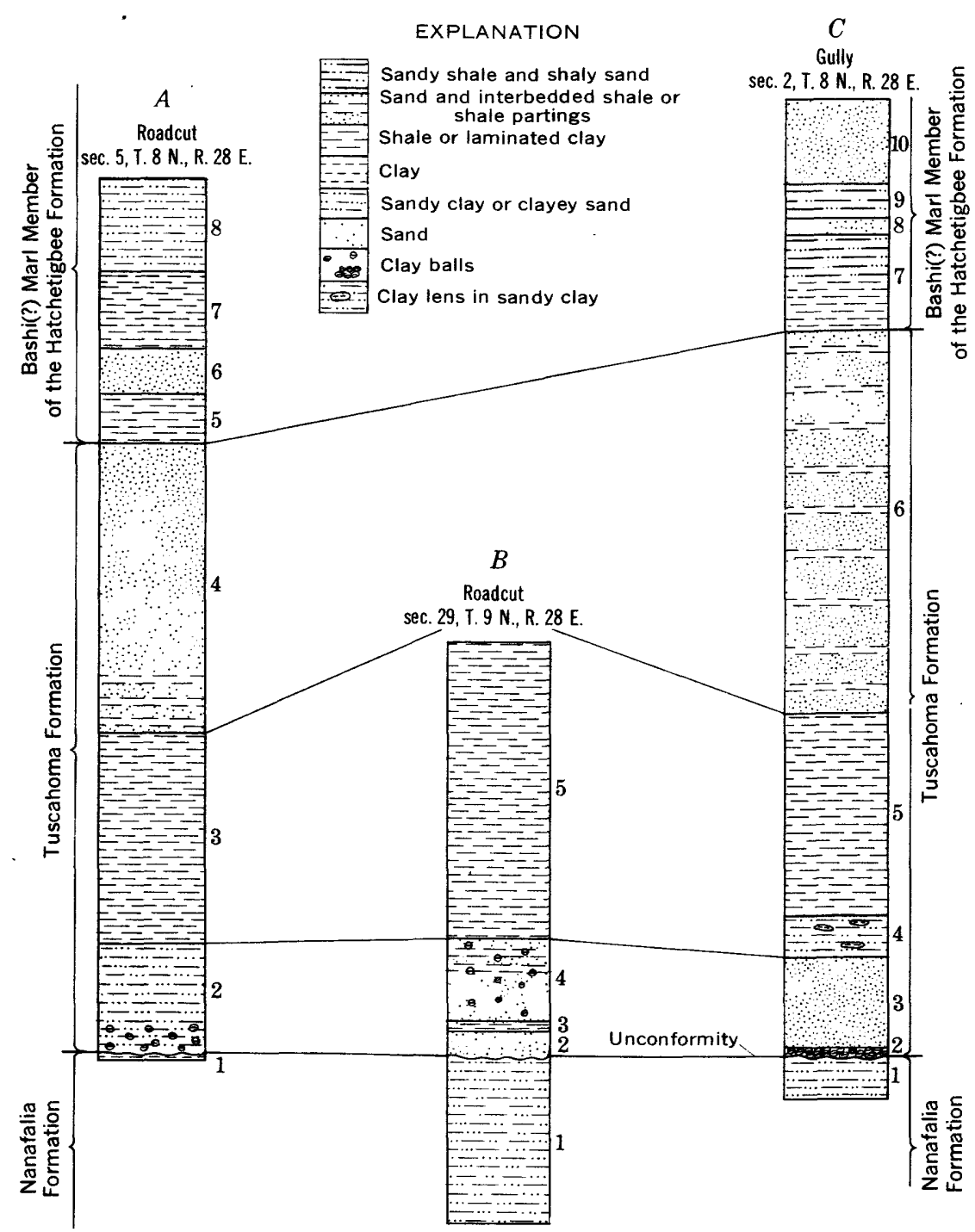

Figure 3.-Correlation chart showing units of the Nanafalia and Tuscahoma Formations and the Bashi(?) Marl Member of the Hatchetigbee Formation. Numbers to the right of the columns refer to the units described in the measured sections in the text. 
The Chlamys bed is not known in the vicinity of Baker Hill, but coarse continental sands present in this area at about the same horizon may represent the bed. Perhaps marine conditions did not extend that far north so early in Tuscahoma time. Southwestward from Baker Hill toward the East Fork of the Choctawhatchee River, the Chlamys bed is rarely found and then, only at below-normal altitudes. This fact suggests that the Chlamys bed was deposited or has been preserved only in the lowest parts of the post-Nanafalia surface. In most of this part of the district, the Nanafalia sediments are directly overlain by coarse thick-bedded red sands and elays of probable Quaternary age.

A light-gray or.green shale or laminated clay, the third member of the Tuscahoma, is present throughout the area mapped, except where it has been removed by erosion. Two fairly consistent features are its light color and shaly appearance on -weathering. Locally, however, it is sandy and massive, and in some places the lower part is carbonaceous and glauconitic. The carbonaceous material is massive and commonly carries small fossils, a Nuculana sp. being the most abundant form. The shale is 20 to 40 feet thick.

The uppermost member of the Tuscahoma Formation, a fine-grained arkose, is also present throughout the district and characteristically consists of bedded sands, crossbedded in part, and thin beds of laminated clay a quarter of an inch to 6 inches thick. The thin clay beds are dislocated in most exposures, showing displacements of a fraction of an inch to several feet.

\section{BASHI(?) MARL MEMBER OF THE HATCHETIGBEE FORMATION}

Bed 5 of section $A$, figure 3, is thought to represent the Bashi Marl Member of the Hatchetigbee Formation because it is at about the same altitude and presumably at the same stratigraphic position as material that resembles the Bashi and that crops out as 2 feet of fine fossiliferous sand in a gully on the east side of the road a quarter of a mile to the north of section $A$. . Beds 5 to 8 in the measured section are considered to be a part of the Bashi. Beds 7 to 10 of section $C$ (fig. 3) are also included in the Bashi(?) Marl Member, although only bed 7 is fossiliferous. These sections are described on pages E30 and E31.

\section{STRUCTURE}

The regional strike, as shown by the base of the Midway Group, is nearly due west in the western two-thirds of the area mapped but swings to about $\mathrm{N} .45^{\circ} \mathrm{E}$. in the eastern part. The dip throughout the area is about 25 feet per mile to the south and southeast. 
Within the area underlain by limestone of the Midway Group, the regional structure is made obscure by extensive leaching of the limestone, which has allowed the overlying beds to slump in a very irregular fashion (fig. 4). Tilted beds, truncated by overlying strata, show that slumping took place throughout Nanafalia time, and abundant sinks in the land surface show that it has continued, perhaps intermittently, to the present. Two Bureau of Mines drill holes punctured pockets of compressed air, possibly trapped by Nanafalia clays when caverns in the underlying limestone collapsed.

In general, the amount of slumping that has taken place is greatest in areas of greatest local topographic relief. For example, the rolling land surface northeast of the Baker Hill cuesta and the valleys in the backslope show the greatest amount, whereas the interstream divides show the least. Many roadcuts show the beds dipping toward the valleys, and the distinctive Chlamys bed of the Tuscahoma commonly occurs at lower altitudes in the valleys than on nearby divides. Deep sinks are scattered throughout the area, however, with the result that dips show little regularity, either in amount or in direction.

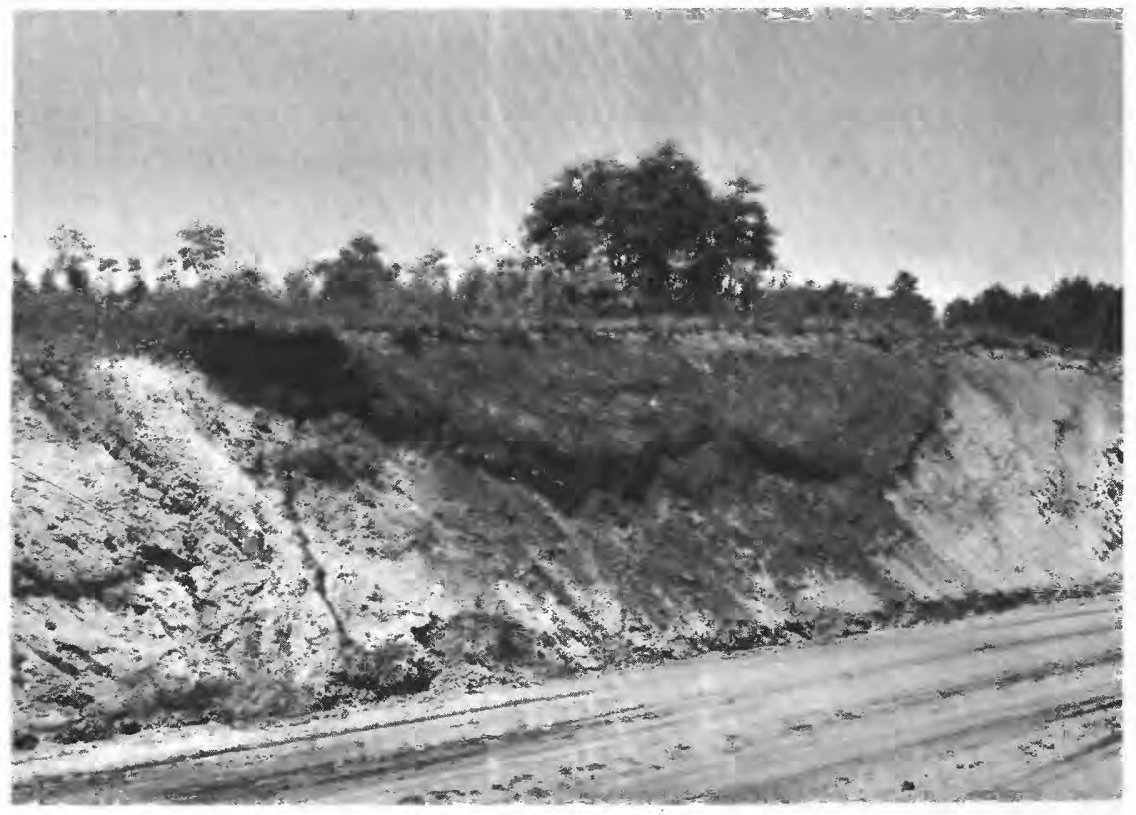

Figune 4.- Sinkhole structure exposed in roadcut, NEI/4 sec. 17, T. 8 N., R. 27 E.; lightcolored sediments in the Nanafalia Formation and dark sand of the Chlamys bed of the Tuscahoma Formation are distorted. 


\section{BAUXITE}

\section{PHYSICAL CHARACTERISTICS}

Two varieties of bauxite are found in the district-a high-iron bauxite known locally as red ore and a low-iron bauxite known as white ore.

By far the greater part of the bauxite is of the low-iron variety (fig. 5). It is characterized by a white, buff, or light-gray color and may be either nonpisolitic or pisolitic. Superficially, bauxite closely resembles kaolin, but more careful examination shows that, whereas kaolin is sticky and dense, bauxite is mealy and porous, even spongy in places. The difference in plasticity is readily observed by chewing a bit of the bauxite or kaolin; this is a common test in this field, though in many other places the chew test is of little value. Although occurrences of bauxite showing no pisolites whatsoever are uncommon, nonpisolitic material composes the bulk of most of the pisolitic bauxites.

The term pisolite, as used in this report, denotes hard spheroidal, concretionlike structures that range from about $2 \mathrm{~mm}$ to more than $2 \mathrm{em}$ in diameter. The pisolites are largely composed of dense porcellaneous gibbsite, permeated by small angular cavities. The larger pisolites are commonly compound and include a number of small ones. Far less common than the hard pisolites are soft, spongy, spheroidal structures, also called pisolites, which appear to be composed of clay. Most of these occur in kaolin and are uncommon in bauxite. There is no consistent relation between the structure of bauxite and its alumina content. Irregular masses of nonpisolitic, pisolitic, and oolitic bauxite may commonly be seen within one deposit, and even experienced miners refuse to guess which of the three is the highest grade.

Red bauxite (fig. 6) is invariably hard and porous but may be either nonpisolitic or pisolitic. The pisolites are commonly 6 or $7 \mathrm{~mm}$ in diameter and of about the same hardness as the matrix. Small veinlets and cavities filled with brown iron oxide are common. The volume per long ton of bauxite in place is about 22 cubic feet.

\section{OCCURRENCE}

The bauxite occurs in kaolin lenses in a continental, predominantly sandy facies of the Nanafalia Formation which was laid down at the time that marine beds in the Nanafalia were being deposited seaward. Except where the kaolin lenses have been eroded or deformed by slumping, the bauxite is confined to the cores of the lenses and grades upward, downward, and laterally into kaolin, the upward gradation being generally the most abrupt. In some deposits the top of the bauxite has been channeled, and the channels have been filled with 

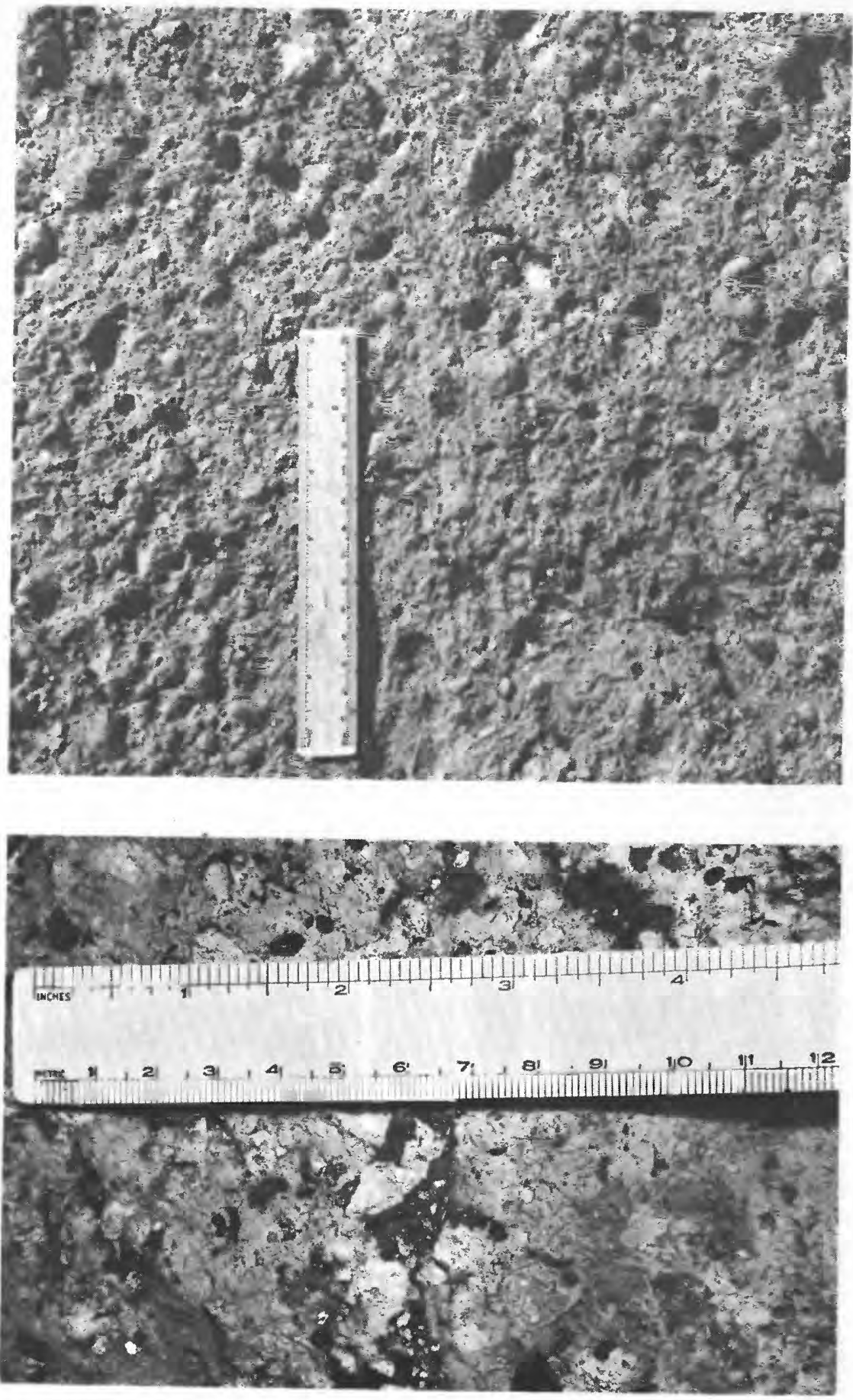

FIGURE 5.-High-grade, low-iron bauxite containing large compound pisolites. The specimen is from a mine in the SE $1 / 1 / 4$ sec. 20 , T. 9 N., R. 28 E. Scale is 6 inches long. 
continental sands of the upper part of the Nanafalia. Individual deposits of bauxite may be lenticular, pot shaped, wedge shaped, or irregular. In part, the irregularity is due to slumping after formation of the bauxite, but, in part, it dates back to the period of formation. In general, bauxite bodies found on the northeast slope of the Baker Hill cuesta, where solution of the underlying limestone has been most pronounced, are irregular in shape, whereas those on the back slope or southwest side of the cuesta are lenticular. The attitude of a bauxite body may be horizontal, undulating or rolling (see figs. $7,8)$, or dipping at any angle up to vertical.

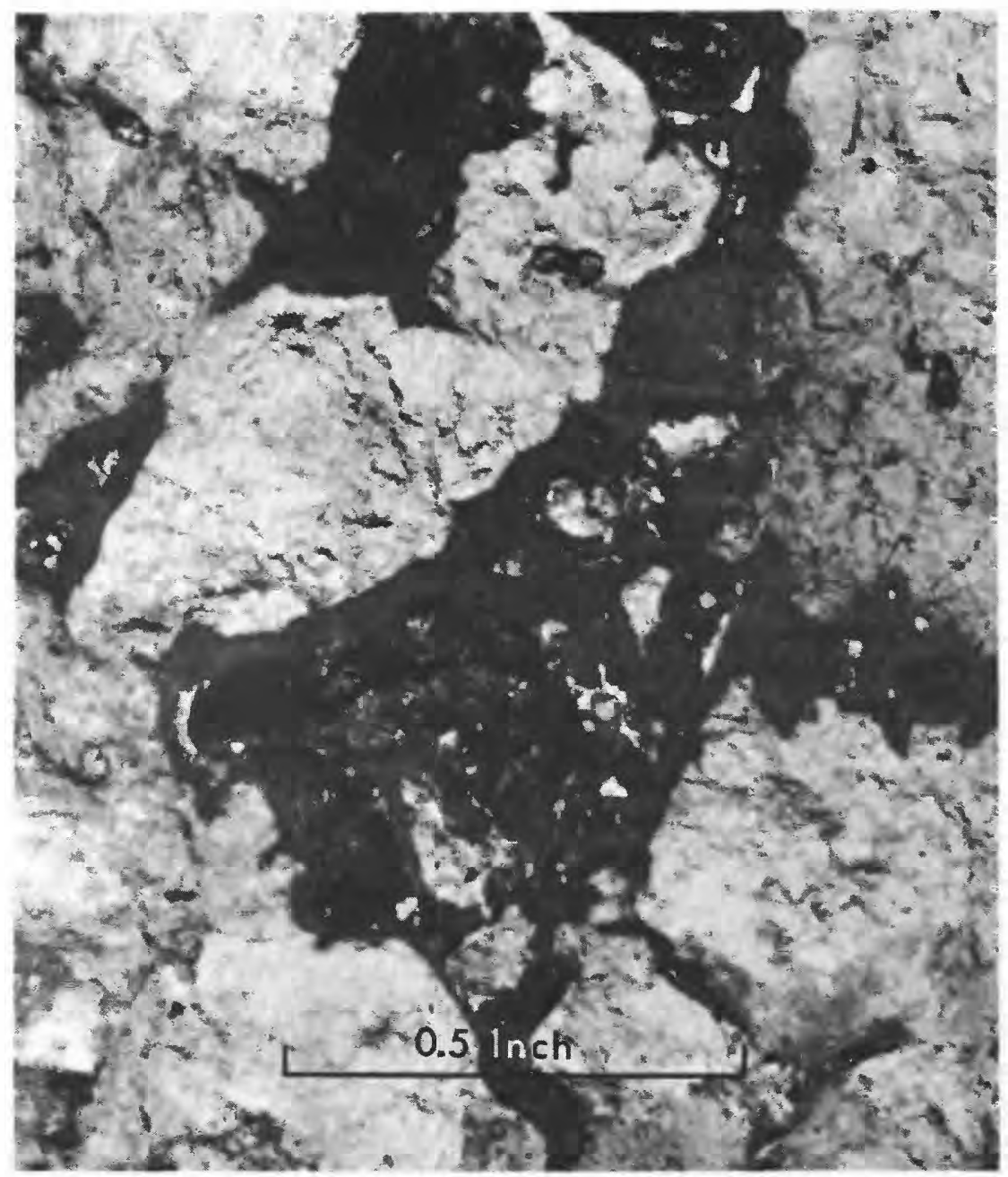

Frgore 6.- Red high-iron bauxite. The specimen is from the F. \& S. Smith mine (Alcoa Mining Co.), NE $1 / 4$ sec. 19, T. 9 N., R. 28 E. Dark material is iron oxide; the white and gray is bauxite having varying amounts of iron oxide. 


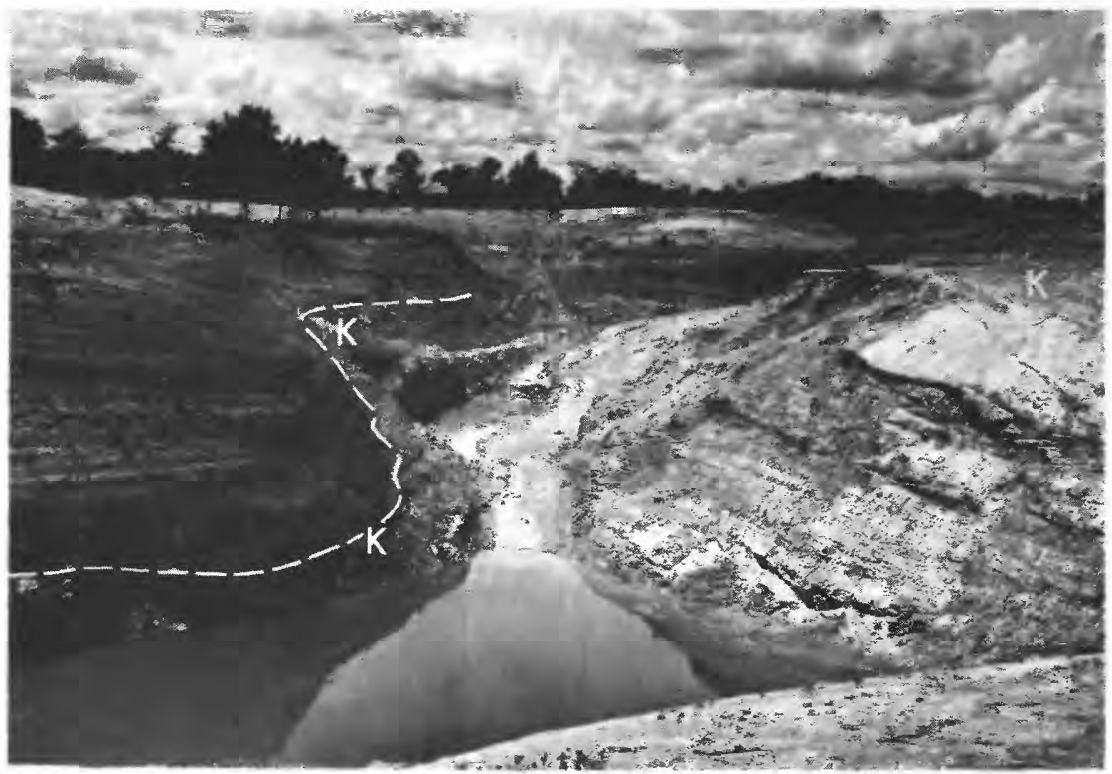

Figure 7.-Roan Baker No. 3 mine (Alcoa Mining Co.), SE1/4 sec. 27, T. 9 N., R. 27 E. The upper surfaces of bauxite and kaolin are parallel and rolling; the surface of the kaolin $(K)$ is exposed at the right side of the picture, but at the left the contact with overlying materials is shown by the dashed line and by the letter $K$. Low areas in the kaolin surface, as at the left center of the photograph, are filted with coarse clean crossbedded sand containing clay balls. The kaolin and sand are overlain by 3 feet of carbonaceous clay, the deformed laminations of which indicate that it was deposited before deformation of the kaolin.

Bauxite bodies range in thickness from 3 to 20 feet and are less than 50 feet to more than 400 feet in length. Known ore bodies contain from a few tons to more than 50,000 long tons of ore; probably less than a dozen mines have produced more than 10,000 long tons, and the average mine production has been about 3,000 long tons. The location of deposits discovered during the joint drilling program of the Geological Survey and Bureau of Mines are shown by symbol on plate 1.

Rarely is red bauxite found beneath the surface, and then, only as small dikelike masses in bodies of low-iron bauxite. Red bauxite is most abundant on the rolling terrain at the base of the northeast slope of the Baker Hill cuesta, where it was probably exposed during the cycle of erosion marked by the Chattahoochee River terrace of Pleistocene(?) age (p. E3). If so, these deposits have been exposed far longer than others in the district. This, together with the fact that the red bauxite commonly grades downward into white bauxite, strongly suggests that the iron oxide that gives red bauxite its characteristic color and induration is secondary and was deposited from 
water high in iron. The presence of such waters is attested by the abundance of thin, hard shells of brown iron oxide throughout the lower Tertiary section, as well as by the red color of the present-day soils in this region.

\section{MINERAIOGY}

Kaolin and bauxite are used here as rock names rather than mineral names-kaolin being a clay composed mainly of kaolinite and bauxite generally being a mixture of gibbsite with variable amounts of kaolinite. Microscopic and $\mathrm{X}$-ray stucies have shown that the bauxite in this district is predominantly a mixture of gibbsite $\left(\mathrm{Al}_{2} \mathrm{O}_{3} \cdot 3 \mathrm{H}_{2} \mathrm{O}\right)$ and kaolinite $\left(\mathrm{Al}_{2} \mathrm{O}_{3} \cdot 2 \mathrm{SiO}_{2} \cdot 2 \mathrm{H}_{2} \mathrm{O}\right)$. Neither boehmite nor diaspore, the monohydrates of alumina, have been detected.

The bauxite and kaolin invariably contain small amounts of iron and titanium. Muscovite, although abundant in most of the continental Nanafalia sediments, is scarce in bauxite and bauxitic clays. Spheroidal pellets of siderite about $1 \mathrm{~mm}$ in diameter are abundant in the kaolin enveloping some bauxite bodies, either above or below the bauxite, or in both positions, and also in kaolins not apparently associated with bauxite. Siderite has not been recognized in bauxite,

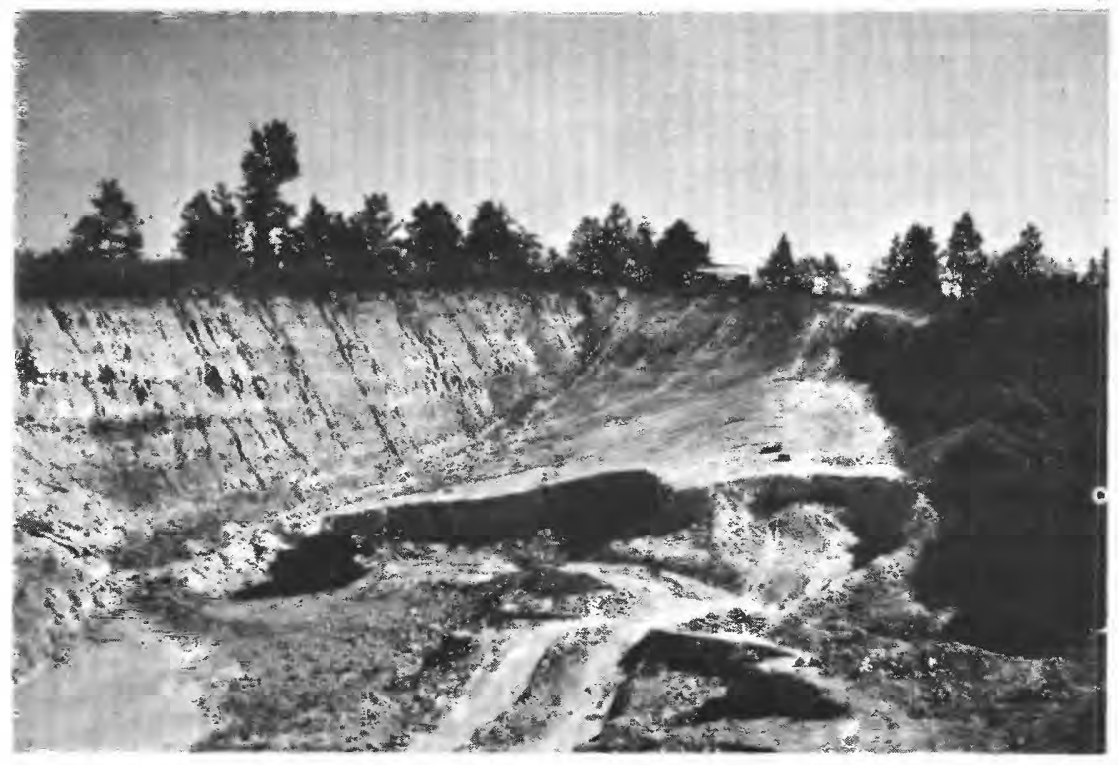

Figure 8.-Sam Smith No. 5 mine (Alcoa Mining Co.), NE1/4 sec. 18, T. 9 N., R. 28 E., showing lenticular bauxite body. Smooth rolling surface beyond car is the top of the bauxite. The mine face in the shadow $t n$ the right of the car represents only a part of the thickness of the bauxite. At the right side of the pit the ore grades laterally into low-grade bauxite, and at the left it becomes too deep for profitable mining. Bauxite is immediately overlain by kaolin which, in turn, is overlain by sand. 
perhaps because of leaching or alteration of the siderite in the more permeable bauxite or the removal of the siderite during the formation of bauxite. Scarce nodules of pyrite have been found in the bauxite deposits in the vicinity of Richards Crossroads but not elsewhere in the district. Quartz is present in varying amounts in the kaolin and, locally, in small amounts in the bauxite. Carbonaceous clay and noncarbonaceous clay containing root markings are common in the Nanafalia Formation. Carbonaceous material is present also in the clay that envelops many bauxite bodies. Some of the kaolin associated with bauxite bodies has been stained a deep bluish red or dark grayish red, probably by some form of iron or manganese.

\section{CHEMISTRY}

Following is a set of partial analyses of samples from two localities. Analyses of samples 1 to 6 show a gradation in depth from bauxitic clay into high-grade bauxite. The analyses were made by the Bureau of Mines (Allen, 1949, p. 29) of core samples from hole Eu-72 put down by drive-pipe drilling in the $\mathrm{N} 1 / 2 \mathrm{NE} 1 / 4 \mathrm{SE} 1 / 4$ sec. $20, \mathrm{~T} .9 \mathrm{~N}$., R. 28 E. Sample 7 is red bauxite from a mine in the NE $1 / 4$ sec. 19, T. 9 N., R. 28 E.

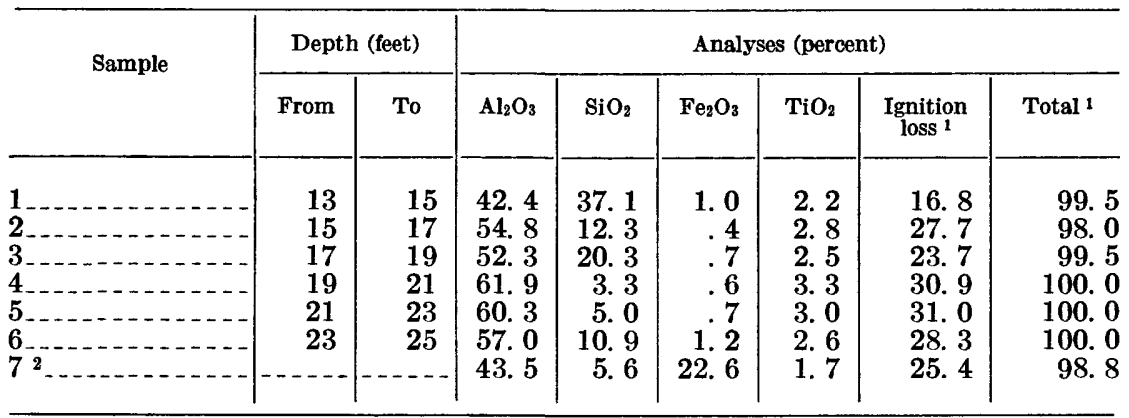

1 Calculated, not given by Allen (1949)

2 Analysis by U.S. Bureau of Mines Lab., Tuscaloosa, Ala. Not in reference by Allen (1949).

If impurities such as iron, titanium, or silica in the form of quartz were not present, the possible range in alumina content from this district. would be from gibbsite containing approximately 65 percent alumina and 35 percent water to kaolinite containing approximately 40 percent alumina, 46 percent silica, and 14 percent water. Inasmuch as impurities are always present, alumina rarely exceeds 62 percent in the bauxite from this district. Iron oxide ranges from less than 1 percent to more than 30 percent, but where it amounts to more than a few percent, it is probably largely secondary. Titania ranges from less than 1 to 4 percent. In the analyses just given, in general 
the samples containing most alumina also have most titania. A statistical study of a large number of analyses from the district shows a very clear increase in titania content from kaolin to high-grade bauxite. The analyses of samples 1 to 6 are unusually consistent. The increase is generally of the order that can be predicted on the assumption that the bauxite has been formed from kaolinite by subtracting silica and adding water, while the titania remains in place. This increase, however, is not invariable.

\section{SUMMARY OF DRILLING PROGRAM}

In November 1941, the Bureau of Mines undertook a program of exploration by drilling; in an effort to expand the known reserves of bauxite in the district. Except for the earliest phase of the work, when attention was confined to blocking out known bauxite bodies, exploration from 1941 through 1943 was based on the studies of the Geological Survev. After the close of Survey work, the Bureau of Mines continued drilling until 1945. Because of the small size of the ore bodies with consequent difficulties in mining, drilling was restricted to areas where overburden would not exceed 50 feet. . Bureau of Mines drilling was further limited by the fact that operators were active in prospecting in the vicinity of known bauxite bodies. In. order to avoid wasteful duplication of work, the Bureau avoided these areas and refrained from fully blocking out the deposits it discovered.

Results of this drilling, locations of holes, and chemical analyses have been published by the Bureau of Mines (Allen, 1949). The locations of holes are shown on section maps; brief logs give thickness of sand and thickness and depth to clay and bauxite together with chemical analyses of bauxite samples. The drilling program can be divided into three parts, in each of which a different type of equipment was used.

A drive-pipe drill was used during the first part of the program, continuing from November 1941 to April 1942. In all, 153 holes were drilled by this means, about half of which were wildcat or located where there was no surface indication of bauxite. Two small bauxite deposits were found, but this type of drilling proved too slow and expensive for wildcat exploration.

The second part of the program lasted for 6 - weeks in June and July 1942. Drilling was done with hand augers in areas where bauxite could be expected under less than 30 feet of overburden. Wildcat holes were arranged in a grid pattern-first, at intervals of 200 feet, and later, at intervals of 400 feet. When bauxite or kaolin was.found, offset holes were drilled 25 feet to 100 feet from the discov- 
ery hole to determine the extent of the bauxite, or, when kaolin was found, to determine whether or not it graded laterally into bauxite. During this phase of the program 279 holes were drilled, and four bauxite bodies totaling 20,000 long tons of commerical grades were discovered. Mines, one of which was the Vinson, were opened in three of the ore bodies almost immediately after they were discovered.

The third part of the program began in November 1942, continued into 1943 , and was by far the most extensive. When this work was completed, most of the favorable prospecting area in the district had been covered. Power-auger drills were used, and holes were arranged in a grid pattern at intervals of 300 feet, with offset holes at intervals of 100 feet, to outline clay and bauxite bodies roughly. Holes were drilled to a depth of 50 feet or to the depth necessary to penetrate the bottom of such clay and bauxite bodies as were discovered. A total of 3,375 power-auger holes were drilled.

Many variables in power-auger sampling preclude making an accurate estimate of the tonnage of individual bauxite bodies. Because the time lag of material coming to the surface is variable, it was impossible to make an accurate measurement of the thickness of the bauxite; contamination of the bauxite as it is brought to the surface through overlying beds of sand and clay lowers the grade an indeterminate amount; and, finally, the 100-foot interval between holes is too great to show the variations in shape and grade of the bauxite bodies in this district. Consequently, more careful blocking out by commercial operators has, in some places, shown estimates based on this type of drilling alone to represent less than half to more than double the amount of ore actually present.

By the end of 1943 , the power-auger program had resulted in the discovery of 39 deposits. In all, 45 deposits totaling 300,000 long tons of commerical grades of bauxite were discovered by the drilling program from its beginning in November 1941. Mines were opened in 10 of these deposits; 50,000 long tons of ore were mined and an additional 70,000 long tons stripped.

The geologic map (pl. 1) shows by symbol the location of deposits of bauxite, irrespective of grade, discovered during the joint project, and the location of bauxite mines and pits, most of which have been mined out. Location of some of the mines and of the deposits has been taken from $A$ ! 1 in $(1949)$.

\section{UTILIZATION AND GRADE OF ORE}

Bauxite from the Eufaula district has been used in the manufacture of metallic aluminum, chemicals, filtering material in petroleum refineries, and refractory brick. Some also is suitable for the manu- 
facture of abrasives, but none is known to have been used for this purpose. The requirements of the various industries differ, and ore which fills the needs of one manufacturer may be entirely unsatisfactory to another. In mining, most of the ore is blended to meet the requirements of the consumer.

In general, the grade of the ore depends on the alumina and silica content, but the amount of iron, although generally low in this district, must also be taken into consideration when bauxite is used for the manufacture of chemicals.

Although bauxite from this district has in the past been used rather extensively for the production of aluminum, the high silica content of much of the ore remaining and probably the relatively small size of the deposits have made competition with foreign sources difficult. Because the iron content of material from the district is generally less than 1 percent, bauxite containing as little as 50 percent alumina and as much as 20 percent silica is used in the manufacture of chemicals. Fire brick and other refractories can be made from material containing considerably more silica and less alumina if the iron content remains low.

\section{PRODUCTION AND RESERVES}

Because of the impetus provided by. World War II, more bauxite was mined in 1942 and 1943 together than in the previous 15 years. In 1942 and 1943 more than 100,000 long tons of bauxite was produced annually. These years marked the peak of domestic production which was reflected in each of the major producing districts of the United States. By 1944, bauxito had been produced from more than 130 mines in the Eufaula district-all of them open pits. Production dropped off rather sharply in both 1944 and in 1945 but remained fairly steady, though low, through the 1950's. Although exact figures are not available, total production in the district through the end of 1960 is estimated, on the basis of the number of mines and their average size, to be about 900,000 long tons.

During World War II the Reynolds Metals Co. maintained a laboratory in Abbeville and bought ore there. All other bauxite produced in the district has been shipped from Eufaula. Some ore is shipped as mined, but inclined rotary-kiln drying plants have been operated from time to time by the Bauxite Co. of Alabama, the Alcoa Mining Co., the Floridin Co., and the General Ore Co.

Bauxite reserves can be estimated only roughly, but measured and indicated reserves of commercial-grade bauxite under overburden not too great to permit profitable mining probably amount to at least 350,000 long tons. The addition of the potential, or inferred, reserves may increase this figure to as much as 600,000 long tons. 


\section{MEASURED SECTIONS}

The measured sections, illustrated in figures 1 and 3 , are described in detail below. The sections in figure 1 primarily show variation in units of the nonmarine part of the Nanafalia Formation. Some sections do not include the whole formation, but others extend from the upper part of the limestone of the Clayton Formation, through the Nanafalia, into the lower several units of the overlying Tuscahoma Formation. The sections in figure 3 show the variation in the Tuscahoma and, where it is exposed, the Bashi(?) Marl Member of the Hatchetigbee Formation.

\section{MEASURED SECTIONS PRIMARILY OF THE NANAFALIA FORMATION}

Section $A$ (fig. 1).-Exposed in a gully in the eastern suburbs of Baker Hill

Tuscahoma Formation:

Thickness

3. Sand, dark-red, crossbedded, poorly sorted. Contains large mica flakes, quartz pebbles half an inch in diameter, and rare kaolin balls. Top eroded.

Nanafalia Formation:

2. Sand, orange, crossbedded, coarse to fine. Contains lenses and stringers of clay balls and quartz pebbles. Mica is scarce in coarse material and abundant in fine material. Grades laterally into sandy micaceous light-gray kaolin within a hundred feet

1. Kaolin, pale-gray, sandy, micaceous. Near the top a part 3 feet thick is interlaminated with medium sand. Top is channeled about 3 feet deep. Base concealed

Composite section $E$ (fig. 1).-Measured at the head of a targe gully and in a hand-auger hole in the bottom of the gully, about 250 yards north of the end of a poor road in sec. $\%, T .8 N$., R. $29 \mathrm{E}$.

Tuscahoma Formation:

Thickness

9. Shale, light-gray. Grades downward into fine, clayey, glauconitic (feet) sand at base. Not measured.

8. Sand, medium, clayey, glauconitic. Contains Ch lamys greggi Harris. Halymenites burrows in lower part extend into underlying unit

7. Sand, white, fine, clayey, glauconitic at top. Grades downward into dark-colored shale interbedded with thin glauconitic sand beds, which in turn grades downward into the underlying unit_-

6. Sand, fine to coarse, glauconitic. Clay-ball zone in the middle and at the base. Contains Halymenites burrows and Chlamys greggi Harris

Nanafalia Formation:

5. Clay, laminated, carbonaceous. Top $2 \mathrm{ft}$ silty

4. Sand, white, fine, clean, micaceous, crossbedded. Contains large mica flakes and abundant dark minerals 
CoMposite seCTION $E$ (fig. 1).-Measured at the head of a large gully and in $a$ hand-auger hole in the bottom of the gully, about 250 yards north of the end of a poor road in sec. $7, T .8 N$., R. $29 \mathrm{E}$.-Continued

Nanafalia Formation-Continued

3. Clay. Section continued in hand-auger hole.

Silty clay

Thickness (feet)

White kaolin 2

Mealy, bauxitic(?) clay 4

White kaolin 3

Black carbonaceous clas 2

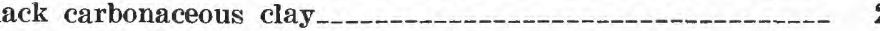

Brown lignite containing pyrite nodules_____________-_ 1

2. Sand, similar to that in bed 4

Midway Group:

1. Limestone, deeply weathered. Base concealed

SeCtIon $D$ (fig. 1).-Exposed in the largest of the Crawford Scott bauxite mines, sec. $35, T .9$ N., R. $27 \boldsymbol{E}$. (fig.10)

Tuscahoma Formation:

Thickness (feet)

14. Shale, gray. Not measured. Grades downward into underlying unit.

13. Sand, coarse, clayey, glauconitic, containing Chlamys greggi Harris

12. Kaolin, white, sandy micaceous (probably reworked Nanafalia) --

11. Sand, coarse, white, strongly glauconitic. Halymenites burrows within bed

Nanafalia Formation:

10. Clay. montmorillonitic(?), black. Contains root markings and a large chunk of carbonized wood

9. Sand, fine, kaolinitic, micaceous, massive. Contains abundant siderite pellets $0.5 \mathrm{~mm}$ in diameter. Lower $2 \mathrm{ft}$ is kaolin containing coarse sand, probably transitional

8. Clay, bauxitic. Contains soft dark-gray pisolites. Top $2 \mathrm{ft}$ nonpisolitic

7. Bauxite, light-gray to light-buff, low-grade. Scattered pisolites in top

6. Bauxite, light-buff, pisolitic, with pisolites up to half an inch in diameter. Grades downward into underlying unit

Section continued in hand-auger hole.

5. Kaolin, yellow, ferruginous.

4. Clay, blue, slightly micaceous; weathers red. Grades downward into next underlying unit

3. Clay, dark-red, ferruginous, containing streaks of gray-brown micaceous sandy clay

2. Sand, light-brown, clayey, fairly coarse, micaceous

1. Sand, light-red, clean, coarse, moderately micaceous. Some large mica flakes 
SECTION $C$ (fig. 1).-Exposed in a cut above the southernmost bauxite pit on the east side of U.S. Highway $241 \mathrm{in}$ SE1/4 sec. 20, T. 9 N., R. $28 \mathrm{E}$.

Tuscahoma Formation:

Thickness

5. Sand, medium, glauconitic, somewhat clayey, fossiliferous. Top eroded (feet)

\section{Nanafalia Formation:}

4. Clay, light-gray, sandy, micaceous, massive. Perforated by Halymenites burrows

3. Sand, white, medium at base, grading into fine at top. Crossbedded, clean, micaceous. Scattered glauconite grains in top, some obviously in Halymenites burrows. No perceptible break between glauconitic and nonglauconitic parts

2. Sand, white, crossbedded, clean. Large mica flakes and scattered quartz pebbles as much as half an inch in diameter

1. Kaolin, bauxitic at base, grades upward into micaceous, sandy kaolin. Upper $3 \mathrm{ft}$ is deep ochrous yellow. Top is channeled, the channels filled with coarse, crossbedded sand containing abundant clay balls. Base concealed

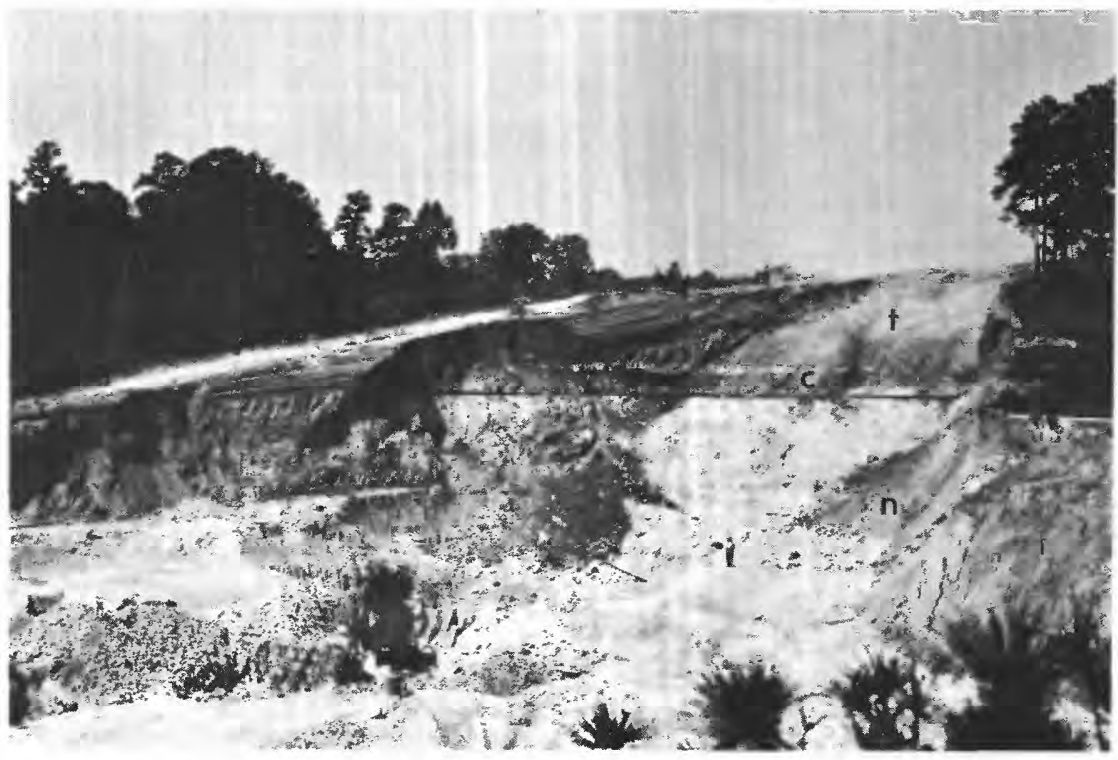

Figure 9.-Crawford Scott mine (Bauxite Co. of Alabama), NE1/4 sec. 35, T. 9 N., R. 27 E. The Nanafalia Formation ( $n$ ), represented by the white bauxite and overlying clay, is unconformably overlain by dark-colored sand and shale of the Tuscahoma Formation ( $t$ ). The thin lens of white clay (c) in the lower part of the Tuscahoma is reworked from the Nanafalia. 
Section $B$ (fig. 1).-Measured in one of the Espy mines, in the NE1/4 sec. 20, T. $9 \mathrm{~N}$. R. $28 \mathrm{E}$.; and in an auger hole in the floor of the mine. All beds in the section represent the Nanafalia Formation.

Nanafalia Formation:

Thicknes8

6. Sand, red, coarse, clean, micaceous. Contains quartz pebbles as much as a quarter of an inch in diameter. Top eroded....--

5. Kaolin, white, clean (feet)

4. Bauxite, white, pisolitic. Pisolites as much as half an inch in diameter. Top pitches steeply. Grades abruptly into overlying kaolin

3. Bauxitic clay

2. Clay, with variations as follows:

Kaolin, grading down from white through yellow to variegated white and red

Clay, yellow, grading down into white

Clay, white to strongly limonitic red

Clay, white to purplish-red

Clay, yellow to red

Clay, white, micaceous

Clay, variegated white and red_.

Clay, white

1. Sand, yellow to nearly white, clayey, becoming limonitic and hard toward base

\section{MEASURED SECTIONS PRIMARILY OF THE TUSCAHOMA FORMATION}

Sectron $A$ (fig. 3).-Measured in a roadcut in sec. $5, T .8 N$., R. $28 E$.

Bashi( ?) Marl Member:

Thickness

8. Sand, fine, clayey; weathers orange brown. Top eroded__-_.- $11+$

7. Shale, green.

6. Sand, fine; weathers yellow brown

5. Shale, green

Tuscahoma Formation:

4. Sand, fine, interbedded with shale near the bottom.

Looks like a weathered arkose. Some crossbedding

3. Clay, light gray, laminated

2. Sand, coarse, glauconitic, clayey. The lower part contains clay balls as large as $1 \frac{1}{2}$ in. in diameter. The upper part includes $4 \mathrm{ft}$ of sandy glauconitic clay.

Nanafalia Formation:

1. Kaolinitic clay, white. Base concealed.

A gully on the east side of the road a quarter of a mile north of the locality where the section was measured shows 2 feet of fine fossiliferous sand closely resembling the Bashi Marl Member of the Hatchetigbee Formation, at about the same altitude as bed 5 in the section. The green shale in the preceding section is therefore thought to be the Bashi Marl Member equivalent. 
Partial Section B (fig. 3).-Measured in the highway cut, sec. 29, T. 9 N., R. $28 \mathrm{E}$.

Tuscahoma Formation:

Thickness

5. Clay, gray, laminated, silty. Blocky when fresh, but exhibits (feet)

a well-defined shaly parting on weathering. A few partings of glauconitic sand near base. Overlain by similar poorly exposed and deeply weathered material up the hill

4. Sand, green, coarse, very glauconitic, containing rounded pellets of green clay as much as a quarter of an inch in diameter. Increasingly shaly toward top

3. Clay, sandy, blocky, laminated ; contains glauconitic partings__-_ 1

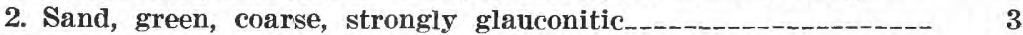
Nanafalia Formation:

1. Clay, white, sandy

Stetion $C$ (fig. 3).-Measured in a gully, sec. 2, T. 8 N., R. 28 E.

Bashi (?) Marl Member:

Thickness

10. Sand, yellow, grading upward into soil 10

9. Sand, shaly, grading upward into sandy shale____.________ 4

8. Sand, fine

7. Shale, grading upward into shaly sand. Fossiliferous and glauconitic at base

Tuscahoma Formation:

6. Sand, loose; contains thin shale partings every few inches. Becomes coarser and crossbedded upward

5. Clay, laminated, gray, massive when fresh, shaly when weathered_ 24

4. Clay, blue-green, sandy, glanconitic, with irregular lenses of gray clay

3. Sand, medium, glauconitic ___ 11

2. Clay-ball conglomerate, glauconitic____ 1

Nanafalia Formation:

1. Sand, white, clayey. Base concealed

\section{REFERENCES CITED}

Adams, G. I., Butts, Charles Stephenson, I. W., and Cooke, Wythe, 1926, Geology of Alabama: Alabama Geol. Survey Spec. Rept. no. 14, 312 p.

Allen, S. A., 1949, Bauxite investigations, Eufaula district, Barbour and Henry Counties, Alabama : U.S. Bur. Mines Rept. Inv. 4521,85 p.

Jones, W. B., 1929, Summary report on the bauxite deposits of Alabama: Alabama Geol. Survey Cire. 7, $36 \mathrm{p}$.

1940, Bauxite deposits of Alabama: Alabama Geol. Survey Bull. 47, 94 p.

Langdon, D. W., 1894, The Tertiary and Cretaceous formations east of the Alabama River, in Smith, E. A., and others, Report on the geology of the Coastal Plain of Alabama: Alabama Geol. Survey Spec. Rept. no. 6, p. 368-445 and 737-745.

Rettger. R. E., 1925, The bauxite deposits of southeastern Alabama: Econ. Geology, v. 20. no. 7, p. 671-686. 
